УДК $349.23 / 24$

DOI https://doi.org/10.32837/pyuv.v1i4(29).399

\author{
Н.П. Пилипчук \\ orcid.org/0000-0002-2926-9340 \\ аспірантка \\ Національної акаделії наук України
}

Інституту держави і права імені В. М. Корецького

\title{
СПЕЦИФІКА КОНСТИТУЦІЙНОГО ПРАВА НА ВІДПОЧИНОК У ЛИТВІ: НАПРЯМИ ЗАПОЗИЧЕННЯ В УКРАЇНУ
}

Слід наголосити, що Україною було обрано напрям на євроінтеграцію, а отже, й аналіз зарубіжного законодавства з питань втілення конституційного права на відпочинок дасть можливість з'ясувати основні його відмінності й особливості, що надалі слугуватиме базою для гармонізації національного та законодавства ЄС. Сьогодні поза межами правового захисту залишаються відносини щодо реалізації права на працю через гнучкий графік роботи, дистанційно або сезонно. Важливо з'ясувати, який вплив така ситуація здійснюе на можливість втілювати право на відпочинок. Також слід визначити, чи існують спеціальні конституційні засоби захисту та забезпечення втілення права на відпочинок, що оптимізують його реалізацію. У свою чергу, саме аналіз зарубіжного досвіду дозволить дізнатися, яким найбільш ефективним чином у нормах права охопити усі такі відносини та закріпити гарантії дотримання заборон і вимог щодо конституційного права на відпочинок усіма суб'єктами права. Також отримані результати допоможуть краще розуміти саму сутність конституційного права на відпочинок i покращити якість юридичної техніки, що, у свою чергу, значно зменшить навантаження на Конституційний Суд України щодо тлумачення норм права та 3'ясування відповідності законодавчих норм щодо права на відпочинок нормам Конституції. У цьому контексті корисним є як позитивний досвід держав, так і негативний, що вказуватиме на можливі перепони та складнощі у реалізації. Це особливо стосується тих держав, які мають схожий із Україною шлях становлення та забезпечення конституційних прав.

Питання зарубіжного досвіду та можливостей до його запозичення в Україну є малодослідженим, окремими його питаннями займалися науковці К.С. Борисова, Т.В. Гавронська, Л.П. Гаращенко, С.Ф. Гуцу, К.І. Дмітрієва, В.М. Завгородня, М.І. Іншин, Л.М. Корольчук, В.Л. Костюк, Є.В. Краснов, П.М. Петровський, О.А. Ситницька, В.В. Собченко, В.В. Тіщенко, О.В. Турата, В.А. Урбанович, В.В. Хромей, І.М. Хуторян.

Литва уже понад15 років є повноцінним членом $\mathrm{CC}$ і протягом цього часу проводить стабільну політику підвищення рівня соціального захисту та захисту соціальних прав, у т. ч. й права на відпочинок. На рівні Конституції Литовської Республіки у ст. 49 встановлено, що «кожна працююча людина має право на відпочинок і вільний час, а також на щорічну оплачувану відпустку. Тривалість робочого часу визначається законом» [1]. Таким чином, право на відпочинок у Литві має ще один особливий вид, а саме право на вільний час. Виходячи з аналізу конституційної норми, його сутність полягає у призначені та способі використання саме позаробочого часу, що не спрямований чітко на відновлення сил. Якщо в українському законодавстві відпустка, до прикладу, по догляду за дитиною теж вважається реалізацією саме права на відпочинок, то Конституція Литви уже більш спеціалізовано регулює таке питання. Варто вказати, що розподіл права на вільний час і відпочинок дозволяє розподіляти й навантаження на працівника та враховувати його сімейні чи інші суспільні обов'язки. Водночас така диференціація має дещо обмежувальний характер, оскільки визначає, що щотижневий відпочинок або відпочинок між робочими днями має бути реалізований виключно на відновлення сил, а отже, і впливає на свободу дій особи. Також із аналізу цієї норми визначається саме залежність робочого часу від тривалості відпочинку, оскільки не врегульовується конституцією та, власне, не володіє варіативністю та чіткими заборонами.

Більш глибоко реалізація конституційного права на відпочинок встановлена Трудовим Кодексом Литви. Так, згідно з ч. 3 ст. 35 «у ході здійснення угод про додаткову роботу не можуть бути порушені встановлені цим Кодексом або іншими нормами трудового права вимоги, що стосуються максимальної тривалості робочого часу і мінімальної тривалості часу відпочинку» [2]. Тобто національним законодавством регулюються не лише загальні питання здійснення права на відпочинок, але й його реалізація залежно від виду роботи. Робота за сумісництвом або робота дистанційно не можуть бути причинами зменшення часу відпочинку. Із цього твердження випливає, що пріоритетним правом є не саме право на відпочинок, а комплекс таких прав, передбачених у Конституції Литви щодо умов праці, щодо 
охорони здоров'я та життя. Зазвичай питання нетипового робочого дня чи обов'язків вирішуються у трудовому контракті, що збільшує можливості тиску з боку роботодавця, а також імовірність настання соціального ризику щодо отримання травми на виробництві, втрати працездатності або звільнення. Саме тому охоплення найбільшого кола суспільних відносин, пов'язаних із правом на відпочинок, є доречним. Для конституційного регулювання це питання є занадто спеціальним, оскільки встановити всі форми виконання роботи неможливо. Ще однією особливістю є наявність посилань не просто на законодавчі акти, а на норми трудового права, а отже, це може бути як сама Конституція Литви, так і закони у сферах цивільного чи адміністративного законодавства, оскільки важливою є не загальна спеціалізація, а направленість конкретної норми. Застосування такої юридичної техніки допомагає уникнути ситуації щодо непоширення на суспільні відносини певного закону через відсутність згадок про нього в основному профільному законодавчому акті. Для українського законодавства таке питання актуальне щодо постанов Кабміну, а також щодо визначення в Конституції України питань для обов' язкової подальшої деталізації.

Відповідно до ч. 5 ст. 52 Трудового кодексу Литви «у разі дистанційної роботи відпрацьований працівником час обчислюється в установленому роботодавцем порядку. Свій робочий час працівник розподіляє на свій розсуд, без порушення вимог, що стосуються максимальної тривалості робочого часу, а також вимог щодо мінімальної тривалості часу відпочинку» [2]. Проблема дистанційної роботи полягає у неможливості повноцінного контролю з боку державних органів, а також у фактичній відсутності зв'язку працівника із професійними спілками чи іншими засобами громадського нагляду та контролю. Відповідно, перевірка стану дотримання вимог про мінімальну тривалість відпочинку та загалом реалізації права на відпочинок суб’єктом є ускладненою. Цю норму можливо тлумачити як заборону для роботодавця щодо офіційного передбачення більшого навантаження на працівника, ніж таке передбачено законом. Однак реальну ситуацію щодо реалізації права на відпочинок така норма може й не врегульовувати. Таким чином, позитивним є крок щодо визнання й закріплення за працівниками, що працюють дистанційно, права на відпочинок, однак ефективних методів забезпечення цього права поки не встановлено.

У цьому контексті важливою є ст. 50 Трудового кодексу Литви, відповідно до якої «працівник має право тимчасово на термін до трьох місяців призупинити виконання трудового договору, в письмовій формі попередивши про це роботодавця за три робочі дні, якщо роботодавець два або більше місяців поспіль не виплачує всю належну працівникові заробітну плату або більш ніж два місяці поспіль не виконує інші свої зобов' язання, встановлені у трудовому і колективному договорі або нормами трудового права, що регламентують час роботи і відпочинку, оплату за працю, безпеку і здоров'я працівників на роботі. У цьому разі працівник звільняється від обов'язку виконувати свою трудову функцію» [2]. Сьогодні українське законодавство не містить оперативних засобів захисту права на відпочинок. Ця норма гарантує реалізацію одночасно конституційних і права на захист, і права на відпочинок. Щодо захисту, то він здійснюється працівником самостійно, що зменшує витрати держави, а також стимулює правомірність діяльності роботодавця. Слід наголосити, що невиконання професійних обов'язків $є$ не лише формою захисту, але й певним чином покаранням роботодавця за порушення умов трудового договору. У такому аспекті обов'язковим є застосування конституційних вимог щодо обізнаності особи й обгрунтованості підстав притягнення до юридичної відповідальності. Щодо останнього, то факти підтверджуються самою документацією, що ведеться роботодавцем. Проте обізнаність забезпечується шляхом повідомлення працівником про припинення виконання професійних обов'язків. Крім того, саме факт повідомлення виступає засобом захисту працівника, оскільки підтверджує факт самозахисту, а не порушення дисципліни праці. Саме право на самозахист у разі порушення права на відпочинок слід закріпити на рівні конституції як окреме, оскільки вона матиме характер як гарантії існування норми в ієрархічно нижчих законодавчих актах, так засобу захисту прямої дії.

Згідно з ч. 4 ст. 107 Трудового кодексу Литви «час відрядження працівника включає в себе час на проїзд працівника до зазначеного роботодавцем місця роботи і назад. Якщо поїздка здійснювалася після закінчення робочого дня, у вихідний або неробочий святковий день, працівник має право на відпочинок такої самої тривалості в перший день після повернення або ж цей час відпочинку додається до часу щорічної відпустки зі збереженням заробітної плати працівника за цей час відпочинку» [2]. Таким чином, визначається й конституційний розподіл вільного часу, тобто самого часу в дорозі та власне часу на відпочинок, який не може бути витрачений в умовах відрядження. Варто наголосити на дуалістичності підходів до вирішення питання про відпочинок. Так, обов'язковою є компенсація через включення вільного часу до робочого. Щодо права вибору реалізація права на відпочинок негайно чи долучення до відпустки, то слід вказати, що воно має бути обмежене залежно від напряму діяльності особи. Так, одним із конституційних обов'язків держави є захист життя 
та здоров'я осіб, мінімізація ймовірності настання соціальних ризиків через реалізацію соціальної політики. У разі відсутності відпочинку після відрядження в осіб, що керують транспортом або виконують роботи, порушення правил охорони праці та технічних вимог на яких може завдати шкоди значній кількості членів трудового колективу, є недопустимим. Відповідно, така норма потребує або деталізації, або ж окремого акта із переліком робіт, для яких обов'язковим є відпочинок саме після відрядження, а не відкладання такого права.

Окремі норми існують щодо права на щотижневий і щоденний відпочинок. Так, ч. 3-4 ст. 122 Трудового кодексу Литви встановлено, що «тривалість щоденного безперервного відпочинку між робочими днями (змінами) не може бути менше 11 годин поспіль, а протягом 7 наступних безпосередньо один за одним календарних днів працівнику повинно бути надано час безперервного відпочинку тривалістю як мінімум 35 годин. Якщо чергування триває 24 години, час відпочинку триває не менше 24 годин» [2]. Тобто встановлено обов'язкову наявність одного повноцінного вихідного, що допомагає повноцінно відпочити та відновити сили без перерв. Потреба саме у повноцінному відпочинку пояснюється фізичними особливостями організму людини та потребою не просто відсутності навантаження, а зміні способу й видів діяльності. Крім того, визначено й мінімальну тривалість відпочинку протягом тижня, потреба у якій пояснюється наявністю різних форм виконання роботи, як робота змінами або ж дистанційна, а також робота понад норму. Тобто реалізація конституційного права на відпочинок залежатиме від обраного особою способу реалізації права на працю. Щодо чергування, то слід наголосити на його не постійності щодо виконання професійних обов'язків. До прикладу, черговому лікарю на зміні може й не доведеться виконувати свої обов' язки, якщо не прийде жоден пацієнт. Водночас відсутня реалізація конституційного права на вільний час, що свідчить про факт втомленості організму. Саме така втома є основним фактором для встановлення відпочинку не менше, ніж сама тривалість чергування. Зі свого боку, формулювання «чергування у 24 години» $є$ встановленням максимальної його тривалості, адже від втоми особи залежить не лише їі життя та здоров'я, але й оточуючих її людей. Оскільки завдання держави - захищати інтереси суспільства, то шляхом нормування максимальної тривалості робочого дня та чергування забезпечуються конституційні права на безпечні умови проживання, свободу дій, безпечне навколишнє середовище для усього населення держави.

Тож на основі проведеного аналізу можливо встановити такі особливості втілення конститу- ційного права на відпочинок за законодавством Литви:

1. Відсильний характер. Так, правове регулювання права на відпочинок часто містить посилання на інші нормативно-правові акти. У межах конституції такі посилання здійснюються на законодавчі акти з метою обов' язковості їх прийняття. Крім того, відсильні норми дозволяють краще розуміти механізм втілення права на відпочинок, а отже, й віднаходити у ньому прогалини чи колізії. Недоліком можливо вважати надмірну навантаженість норм права та можливість хибного тлумачення без охоплення усіх частин норми, що можуть міститися в різних законодавчих актах. Саме тому важливим є встановлення на рівні конституції найбільш загальних прав щодо реалізації права на відпочинок та обов' язків держави.

2. Компенсаційний характер. Так, конституційні права на працю та відпочинок повинні взаємодіяти між собою, однак реалізація одного права не повинна перешкоджати чи обмежувати свободу в реалізації іншого. Так, у межах литовського законодавства надурочні роботи або роботи змінами, що потребують більшого часу роботи, повинні компенсуватися або ж через рівень заробітної плати, або через надання вихідних більшої тривалості. Важливо, що розмір компенсації не є спільним для всіх, а залежить від виду роботи та ïi тривалості. Таким чином, відбувається гарантування інтересів усіх осіб, що працюють.

3. Всеохоплюваність. Щодо конституційних норм, то вони охоплюють усі випадки реалізації права на відпочинок, його захисту та забезпечення, що дозволяє деталізувати їх на рівні закону. Проте саме рівень закону, а не інших нормативно-правових актів є чітко встановленим. На відміну від українського законодавства щодо права на відпочинок, яке об'єднує, крім основного акта (Кодексу законів про працю) також закони щодо видів права на відпочинок, підзаконні нормативно-правові акти щодо реалізації окремих видів права на відпочинок, литовське законодавство регулює особливі випадки разом. Тобто диференціація здійснюється в межах одного законодавчого акта. Така ситуація значно зменшує можливість помилкового видозмінення призначення норми права щодо відпочинку та виникнення колізійних ситуацій. Таким чином, завдяки всеохоплюючому характеру Конституції зменшується навантаження на суди та законодавчі органи щодо виправлення помилок юридичної техніки.

Виходячи з особливостей і позитивних відмінностей правового регулювання конституційного права на відпочинок, у Литві можливо дійти висновку, що необхідним є розподіл права на відпочинок. Таким чином, Конституцію України варто доповнити новою нормою 45-1, яка повинна мати такий зміст: «Кожен, хто 
працює, має право на вільний час. Держава гарантує реалізація права на вільний час шляхом встановлення у законі соціальних, творчих відпусток, відпусток у зв'язку із підготовкою до змагань та/чи у зв'язку з навчанням». Таким чином, право на відпочинок більше не суперечить самій меті щодо відновлення сил, однак через соціальні та інші відпустки як спосіб проведення часу поза виконанням професійних обов'язків є засобом соціалізації особи, а отже, стосується конституційних прав особи на свободу дій і думки. Таким чином, саме передбачення на рівні Конституції України окремих видів прав, що використовують вільний від роботи час своєї реалізації, значно спрощує систему їх реалізації та тлумачення самих норм права для їх застосування. Крім того, включення переліку відпусток до гарантій визначає обов'язок роботодавця щодо їх надання. У свою чергу, це вже впливатиме на самий рівень навантаження на особи, яка працює, а отже, і на їі втомлюваність і потребу у відпочинку.

Крім того, варто доповнити Кодекс законів про працю України новою ст. 83-1 щодо можливості працівників самостійно реалізовувати право на відпочинок. Так, ця норма повинна мати такий зміст: «Працівник має право тимчасово на термін до двох місяців призупинити виконання трудового договору, в письмовій формі попередивши про це роботодавця за два тижні, якщо роботодавець більше півроку з моменту звернення не виконує обов'язок щодо надання щорічної, додаткової, соціальної відпустки. У цьому разі працівник звільняється від обов'язку виконувати свою трудову функцію». Таким чином, реалізується конституційне право як на захист, так і на відпочинок. Крім того, відсутність потреби у залученні держави значно скорочує витрати державного бюджету.

\section{Jimepamypa}

1. Lietuvos Respublikos Konstitucija: Lietuvos Respublikos piliečių priimta $1992 \mathrm{~m}$. spalio $25 \mathrm{~d}$. Referendume. URL: https: cutt.ly/rrMctlg (дата звернення: 19.09.2019).

2. Lietuvos Respublikos darbo kodekso patvirtinimo, isigaliojimo ir igyvendinimo istatymas: 2016 m. rugsejo 14 d. № XII-2603 Vilnius. URL: https: cutt.ly/rrMclUF (дата звернення: 19.09.2019).

\section{Анотація}

Пилипчук Н. П. Специфіка конституційного права на відпочинок у Литві: напрями запозичення в Україну. - Стаття.

У статті проаналізовано специфіку реалізації конституційного права на відпочинок у Литві. Виведено особливості забезпечення цього права людини та громадянина. Наведено обгрунтовані напрями запозичення у національне конституційне законодавство. Вказано на спільні та відмінні ознаки забезпечення конституційного права на відпочинок в Україні та в Литві.
Визначена необхідність доповнити Конституцію України новою нормою 45-1, яка повинна мати такий зміст: «Кожен, хто працює, має право на вільний час. Держава гарантує реалізація права на вільний час шляхом встановлення у законі соціальних, творчих відпусток, відпусток у зв'язку із підготовкою до змагань та/чи у зв'язку з навчанням». Таким чином, право на відпочинок більше не суперечить самій меті щодо відновлення сил, однак через соціальні та інші відпустки як спосіб проведення часу поза виконанням професійних обов'язків є засобом соціалізації особи, а отже, стосується конституційних прав особи на свободу дій і думки. Таким чином, саме передбачення на рівні Конституції України окремих видів прав, що використовують вільний від роботи час своєї реалізації, значно спрощує систему їх реалізації та тлумачення самих норм права для їх застосування. Крім того, включення переліку відпусток до гарантій визначає обов'язок роботодавця щодо їх надання. У свою чергу, це вже впливатиме на самий рівень навантаження на особи, яка працює, а отже, i на ї̈ втомлюваність і потребу у відпочинку.

Зроблено висновок щодо доцільності доповнити Кодекс законів про працю України новою ст. 83-1 щодо можливості працівників самостійно реалізовувати право на відпочинок. Так, ця норма повинна мати такий зміст: «Працівник має право тимчасово на термін до двох місяців призупинити виконання трудового договору, в письмовій формі попередивши про це роботодавця за два тижні, якщо роботодавець більше півроку з моменту звернення не виконує обов'язок щодо надання щорічної, додаткової, соціальної відпустки. Працівник звільняється від обов'язку виконувати свою трудову функцію» .

Ключові слова: конституційне право, право на відпочинок, конституційне законодавство, конституційні норми, конституція.

\section{Summary}

Pilipchuk N.P. Specificity of the constitutional right to rest in Lithuania: directions of borrowing to Ukraine. - Article.

In the article the specifics of the implementation of the constitutional right to rest in Lithuania are analyzed. The peculiarities of securing the given human and citizen rights are shown. The substantive directions of borrowing in the national constitutional legislation are given. The common and distinctive features of ensuring the constitutional right to rest in Ukraine and in Lithuania are indicated.

The necessity to amend the Constitution of Ukraine with a new rule 45-1 has been determined, which should have the following meaning: "Everyone who works has the right to free time. The state guarantees the exercise of the right to leisure by establishing in the law social, creative leave, vacations in connection with the preparation for competitions and/or in connection with training. "Thus, the right to rest is no longer at odds with the goal of recuperation, but through social and other vacations, as a way of spending time outside the performance of professional duties is a means of socializing the individual, and therefore concerns the individual's constitutional rights to freedom of action and thought. Thus, the very prediction at the level of the Constitution of Ukraine of certain types of rights that use their time off from their work significantly simplifies the system of their implementation and interpretation of the rules of law themselves for their application. In addition, the inclusion of a list of 
holidays in the guarantees determines the obligation of the employer to provide them. In turn, this will already affect the level of workload on the person who is working, and thus his fatigue and need for rest. It is concluded that it is advisable to supplement the Labor Code of Ukraine with a new Article 83-1 on the possibility for employees to exercise their right to rest independently. Yes, this provision should have the following meaning: "the employee has the right to suspend the employment contract temporarily for up to two months, in writing, warning the employer about this in two weeks, if the employer does not fulfill the obligation to provide annual leave for more than six months, extra, social leave. In this case, the employee is relieved of his duty to perform his work function".

Key words: constitutional law, right to rest, constitutional legislation, constitutional provisions, constitution. 